\title{
Active learning methodologies: possible paths to innovation in health teaching
}

\author{
Metodologias ativas de aprendizagem: caminhos possíveis para inovação no ensino em saúde \\ Metodologías activas de aprendizaje: caminos posibles para la innovación en la enseñanza en salud
}

\author{
Kelly Dandara da Silva Macedo ${ }^{1}$ \\ Beatriz Suffer Acosta ${ }^{1}$ \\ Ethel Bastos da Silva ${ }^{1}$ \\ Neila Santini de Souza ${ }^{1}$ \\ Carmem Lúcia Colomé Beck ${ }^{2}$ \\ Karla Kristiane Dames da Silva ${ }^{3}$
}

\footnotetext{
1. Universidade Federal de Santa Maria. Palmeira das Missões, RS, Brasil.

2. Universidade Federal de Santa Maria. Santa Maria, RS, Brasil.

3. Instituto Federal do Rio de Janeiro.

Rio de Janeiro, RJ, Brasil.
}

Corresponding author:

Ethel Bastos da Silva.

E-mail: ethelbastos@hotmail.com

Submitted on $01 / 17 / 2018$.

Accepted on $04 / 28 / 2018$.

DOI: 10.1590/2177-9465-EAN-2017-0435

\begin{abstract}
Introduction: Teaching qualification about active learning methodologies is a potential for the transformation of practices. Aim: To report the experience of teachers in the discussion of active learning methodologies as a problematizing pedagogical strategy for higher education in health. Method: This is an experience report with teachers from a public university in the northwestern region of the state of Rio Grande do Sul/Brazil. Six teaching workshops based on the Arch of Charles and Maguerez were implemented alongside the teachers of the nursing, nutrition and biology courses. The use of active methodologies in health teaching was problematic and the themes "evaluation, reflective portfolio and conceptual map" were theorized. Result: The problematization with the Arch of Charles and Maguerez facilitated the understanding and the applicability of the active methodologies. Conclusion: There are prospects for the inclusion of active learning methodologies in teachers' practice, which may become a pedagogical strategy and attend to DCNs in this scenario.
\end{abstract}

Keywords: Problem-Based Learning; Teaching; Education Higher; Nursing; Health Education.

\section{Resumo}

Introdução: A qualificação docente sobre metodologias ativas de aprendizagem é potencial para a transformação de práticas Objetivo: Relatar a experiência de docentes na discussão de metodologias ativas de aprendizagem como estratégia pedagógica problematizadora para o ensino superior em saúde. Método: Trata-se de um relato de experiência realizado com a participação de docentes de uma universidade pública da região noroeste do estado do Rio Grande do Sul-Brasil. Foram implementadas junto aos docentes dos cursos de enfermagem, nutrição e biologia seis oficinas pedagógicas com base no Arco de Charles e Maguerez. Problematizou-se o uso de metodologias ativas no ensino em saúde e teorizaram-se os temas "avaliação, portfólio reflexivo e mapa conceitual". Resultado: A problematização com o Arco de Charles e Maguerez facilitou a compreensão e a aplicabilidade das metodologias ativas. Conclusão: Há perspectivas de inclusão de metodologias ativas de aprendizagem na prática dos docentes, podendo tornar-se estratégia pedagógica e atender às DCNs nesse cenário.

Palavras-chave: Aprendizagem Baseada em Problemas; Ensino; Educação Superior; Enfermagem; Educação em Saúde.

\section{REsumen}

Introducción: La cualificación docente sobre metodologías activas de aprendizaje es potencial para la transformación de prácticas. Objeto: Relatar la experiencia de docentes en la discusión de metodologías activas de aprendizaje como estrategia pedagógica problematizadora para la enseñanza superior en salud. Método: Se trata de un relato de experiencia realizado con docentes de una universidad pública de la región noroeste del estado de Rio Grande do Sul/Brasil. Se implementaron junto a los docentes de los cursos de enfermería, nutrición y biología seis talleres pedagógicos basados en el Arco de Carlos y Maguerez. Se planteó el uso de metodologías activas en la enseñanza en salud y se teorizó los temas "evaluación, cartera reflexiva y mapa conceptual". Resultado: La problematización con el Arco de Charles y Maguerez facilitó la comprensión y la aplicabilidad de las metodologías activas. Conclusión: Hay perspectivas de inclusión de metodologías activas de aprendizaje en la práctica de los docentes, pudiendo convertirse en estrategia pedagógica y atender a las DCNs en este escenario.

Palabras clave: Aprendizaje Basado en Problemas; Enseñanza; Educación Superior; Enfermería; Educación en Salud. 


\section{INTRODUCTION}

Graduate education in health goes through deep transformations to attend changes in the academic training of students and, for that, it needs to incorporate pedagogical strategies with an approach centered in the student as a promoter of it's own educational action, in which this transit from depending the professor to autonomy and elaborates it's knowledge on fulfilling proposed educational activities. ${ }^{1}$

Active methodology (AM) has a critical reflexive education conception based on the stimulous of the learning-teaching process, resulted in involvement by the student in the search for knowledge. Inside the active methodology concept, there is a method based on constructing a problem situation (PS), which enables critical reflection; it mobilizes the student to seek knowledge, in order to solve the PS; it helps on reflection and proposition of more adequates and correct solutions. ${ }^{2}$ Theoretical and methodological conceptions converge with the Problematization Methodology (PM). ${ }^{3}$

On Problems Based Learning (PBL), the professor present a problem close to real or simulated elaborated by expertises in the area of knowledge, with fundamental themes that enable the student's preparation to act on the professional life. Themes/contents related to the problem are studied individually or collectively and are discussed in the group. The professor will wake the student's feeling that he is capable of solving issues, from research. ${ }^{2}$ This proposal "enables the stuent to employ adquired knowledge in an amplified form, minimizing the occurance of a fragmented education". ${ }^{4}$

Problematization methodology is present in some methods that can subside the teaching, among them the already cited Problems Based Learning (PBL), Team BasedLeraning (TBL), o Charles and Maguerez Arch and Project Based Learning (ProjBL). These last two differ from the rest, because they work with a real PS and the study occurs to solve it. ${ }^{4}$

Construstivist spiral (CS) is a new AM problematizer that has a theoretical framework on the constructivist education conception, on dialogue, on scientific methodology and meaningful learning. ${ }^{5}$ On meaningful learning, according to David Ausubel, the professor tends to activate subsumes present in the student, waking him up to impregnate him with different notions, changing and tuning those already existing. Learning happens when it makes sense on cognitive structure based on knowledge, on experience and on intellectual capacity, so that the new knowledge is processed and the student can express it. ${ }^{6}$

David Ausubel proposed the Meaningful Learning Theory, which describes the cognitive process of a person on obtaining new knowledge. So that meaningful learning happens, it is fundamental that some key-points are considered: student's previous knowledge; activity instruction, that should be meaningful; and that the student, must pick to apprehend meaningfully. ${ }^{7}$
Problematization with the Charles and Maguerez Arch in teaching is potent to raise student's curiosity, and during the theorization step, research can bring new information still not thought by professors. This accepted and valued knowledge wake the student's feeling of competence, engagement and commitment with his own knowledge. ${ }^{2}$

Problatizating AM MA is fundamented in the theoretical framework of Paulo Freire, whose conception is based on freeing, dialogic, reflexive, conscienting, transformative and critical education, in which problems come from a reality. ${ }^{8}$

Independent from the choice made, Higher education institutions $(\mathrm{HEI})$ recognize the need to adopt problematizing $\mathrm{AM}$, if not in all curriculum, in disciplines which professors refine themsevels with the proposal and which insert themselves with support in it's practices. ${ }^{1}$ This way, professors in the public health and administration area, for exemple, can produce ways to educate, that stimulate production on knowledge based on solution of pratical and complex issues observed in the reality of health services on Primary Health and Hospital Care. These pedagofical actions occur in an articulated and integrated form among workers, users and civil society and converge with health services proposals. ${ }^{1}$

Ministry of Education, through National Education Base and Guidelines Law and Resolution CNE/CES n.․ 03/2001, recommends AM as an strategy to develop competencies and abilities on training the nurse. ${ }^{9}$ In this direction, there are evidences to adopt AM in undergraduate courses with inclusion of critical pedagogy concepts - such as problematization and autonomy -, and, with this, the student's approximation to society's health reality. ${ }^{10}$

Parallel to it, reinforcing this vision, Ministry of Health (MH) proposes AM in professionals' training, articulated in the movement of organizing models of attention, in order to incorporate these in the curriculat structure. This because on undergraduate courses in the health area and Primary Healh Care Policies, need to be in accordance with ways to produce promotion actions, from real pratical problems that require transformation/solutions. ${ }^{11}$

Active learning methodologies are used in various places in the world and, even though they present it's limitations, they demonstrate positive results in the student's autonomy. ${ }^{4}$ Problematization is the main methodology used, however the lack of theoretical frameworks to plan pedagogical action and the excessive use of teaching techniques don't characterize, in fact, the method. ${ }^{3}$ For that reseon, students sinalize the need for professor's qualification to use these methodologies. ${ }^{3-6-12}$

Considering these assumptions, researchers of a public university of Rio Grande do Sul's Northwest region implemented a project for professors' qualification that enables a group of professors to discuss and reflect on AM. We present as aim to relate the experience of a group of professors in discussing active methodologies as a problematizing pedagogical strategy for higher education in health. 


\section{METHOD}

It's an experience report of a project of professor's qualification, having as basis the educational action developed through pedagogical workshops for higher education in health professors from Federal University of Santa Maria (UFSM), Campus Palmeira das Missões. The project was idelized and conducted by two professors from the Nursing Course UFSM, Campus Palmeira das Missões and one of the Campus headquaters of UFSM, and by a professor from the physiotherapy course on the Federal Institute of Rio de Janeiro (IFRJ), all with experience in the use and training of professors in AM.

Six pedagogical workshops with UFSM, Campus Palmeira das Missões, professors' participation were developed, situated in the northwest region of Rio Grande do Sul, Brazil. Criteria for participation were: be a professor in the higher education course in health, being interested and availability to participate in the workshop.

Project's development period comprehended months of august to November of 2017. Workshops were developed on Wednesdays, from $13 \mathrm{~h} 30 \mathrm{~min}$ to $16 \mathrm{~h} 30 \mathrm{~min}$, in a UFSM classroom reserved for this end.

Before the first workshop, organization group - constituted by two professors by the headquarters institution and two students with a schoolarship - made and delivered printed invitations personally, sent emails to all professors by the Nursing, Nutrition and Biology professors of UFSM Campus Palmeira das Missões. Participants confirmed participation and justified absenses. Quantitative of participants varied in each workshop and the average was of seven professors.

In all workshops, participants signed a presence list, sitted in chairs disposed as a circle, received informations pertinent to the project and sigend the Free and Informed Consent Form, authorizing recording of dicussions and the use of those for scientific ends. Ethical principals were respected, according to Resolution n. ${ }^{\circ}$ 466, of 2012, from Health's National Counsil.

For workshops development, the Problematization Methodology (PM) employed was Charles and Maguerez Arch, ${ }^{13}$ which present five steps. EC methodology was mixed to enable professors' experiences with learning doing, being experienced on the Theorization step. In the first step, participants observed reality and identified the problem with the theme "AM and pedagogical strategies on teaching practice", which corresponded to the first workshop. On the second step, they identified key concepts, which occurred in the second workshop. On the third step, Theorization was done, which corresponded to the third, fourth and fifth workshops. On the fourth and fifth steps, were also planned solution hypothesis and application to reality, which occurred in the sixth workshop. Figure 1 illustrates the development of these steps. ${ }^{14}$

On Theorization step of Charles and Maguerez Arch, six EC movements were adopted-problem identification, hypothesis formulation, elaborating issues of learning - "provisional synthesis,
Figure 1. Steps of the Methodology study development of active learning according to the Charles Magueres Arch, adapted from Bordenave; Pereira (1989).

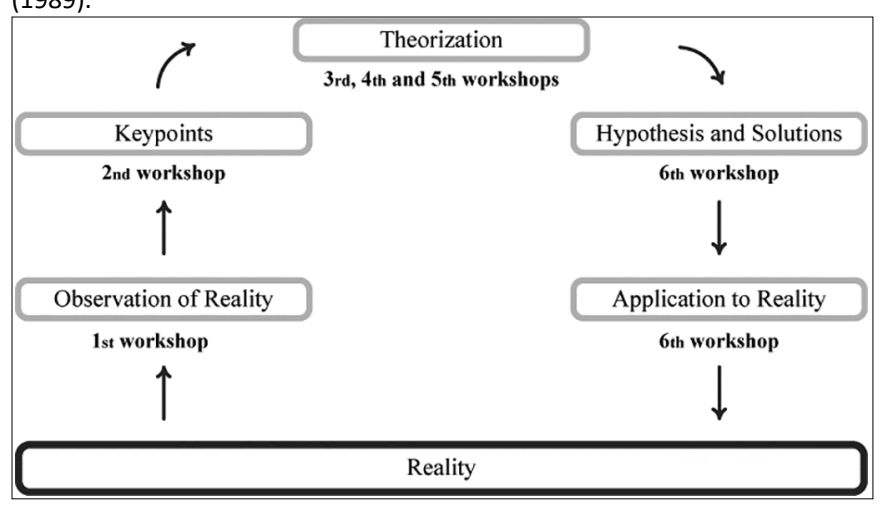

search of new information, construction of new meanings and evaluation/"new synthesis". Problem situation (PS) is a mobilizer, professor/mediator is encouraging of critical and reflexive capacity of students. Evaluation is done by the end of it in a cycle and can generate the need to new themes for discussion. ${ }^{5}$

With this, nursing and physiotheraphy professors responsible by the elaboration and planning the project constructed PS with correlated themes. The group received instructures about EC phases, they were welcomed by a coordinator and rapporteur among participants, function this alternated on following workshops so that all had the opportunity to experience this place in the teaching-learning process. Participants, coordinators and rapporteurs were guided to conduct the activity, initiating pactualization on the form of work, time for PS individual reading, problems' identification and elaboration of issues with the help from the rapporteur on the board. Result was the construction of provisional synthesis, the search for new information, construction of new meanings and evaluation, resulting in a new synthesis. Each workshop lasted approximately two hours.

\section{RESULTS AND DISCUSSION}

Next, results from the experience of problematization about methodologies of active learning are presented, according to Charles and Maguerez Arch, ${ }^{13}$ and discussion based on theoretical foundation.

\section{Observation of the reality - the first workshop}

In this, the group responsible by the project execution, constituted by two UFSM nursing professors - Campus Palmeira das Missões, exposed the proposal with the work's aim and methodology. Participants presented themselves and shared their expectations, doubts, previous experiences and approximation with active methodologies. From that on, the organization of activies was agreed according to place/room for the workshops, time, day of the week and dates. The responsible group created a communication tunnel in the application WhatsApp to exchange information with participants about the workshops. 
Professors' motivation to participate in the discussion group was to know AM and deepen knowledge about theoretical, methodological conceptions and forms of evaluation the teaching-learning process, with the possibility to include disciplines because their pedagogical practices using expositive classes strategies didn't totally fulfil the needs of high education students. We highlight that great part of professors had affinity with the theme and had already experienced it in extension projects. Most of them showed worrisome with the inclusion of AM in disciplines, especially according to the content to be approached, involvement and commitment this pedagogical methodology require.

Narratives reinforce dissatisfaction from professor with their pedagogical practices and the desire to discuss AM collectively. Identification of these traditional pedagogical practices, insufficient to motivate the student to attend new challenges and contemporaneity requirements, were also contemplated in study with the theme. ${ }^{4}$ The lack of motivation of the student to obtain knowledge through an expositive class may be related to controlling pedagogical practices and with rewards that are sometimes not encouraging. ${ }^{4}$

Even though AM is a method with beneficial proofs, it is necessary professors and students believe in it's pedagogical potential and commit to work intellectually and affectively to construct learning. Empathy with the professor facilitates the process of teaching-learning. We highlight, however, that the method, only doesn't have potential to develop autonomous motivation of the student. ${ }^{2}$

"Recognizing the complexity of the teaching-learning process and the existence of their own knowledge by university teaching refer to professor's professionalization". 13:441

Upon this, professors initiated seeking instrumentalizing knowledges in innovative practices that, on being incorporated by quotidian, can surpass complex and challenging reality of education in health.

\section{Key Points-Second workshop}

The workshop began with the delivery of paper cards and atomic pencil for professors, being oriented that they answered to generated questions: How are my classes? What are the most common manifestations of students on classes? The aim of this moment was to problemtize planned classes with professors, in order to discuss AM. As they responded, they glued the cards on the board.

Narratives revealed concern in provide theoretical programmatic content in expositive classes with answers to professors to students' questions and, eventually, intercalated with interative and participative methods such as games, videos and case discussions. Teaching plans were organized in theoretical blocks taught before practical block. Professors' practices showed themselves as dichotomized. The evaluation was summative, the theory measured by evidence and practice by the development of skills and competences according to disciplines' aims.
Study show these actions happen in fragmented disciplines, organized in a way students receive, first, theoretical content and, after, experienced practical classes. ${ }^{15}$ This vision reveals a pedagogical practice of teaching centered in the professor as holder of knowledge and in the Cartesian/flexnerian paradigm, considering fragmentation and specialization of knowledge. In this aspect, it is recommended the greater openness to teaching-learning strategies that bring theory and practice closer to concrete social reality. ${ }^{16}$

The notion that students receive theoretical content chosen and exposed by professors and evaluated in tests with good knowledge retention, presenting better abilities and competences in practice, was present in the professors' statements. This is a model that distances itself from the formative, but that responds to an institutional policy in which the student's learning is fragmented and measured by the note of each discipline. ${ }^{4}$

Some professors experienced situations in which students received theoretical knowledge, were evaluated with tests and presented a low level of learning but, when they went to the practical field, they developed abilities and competences. When students feel valued by their competences, they commit themselves with their own learning, becoming active. ${ }^{4}$ Beyond that, to be in health services with a professor, promotes integration between practice and theory, and such experience can raise motivation for learning.

Other professors observe that there are disciplines, such as "Supervised internship", passable of working with problematization with real cases. They expressed that students feel challenged and stimulated to research theory, discuss situations and propose solutions, however uncomfortable related to evaluation because this occur based on expressed and described theoretical-practical reflections, that show capacity of knowledge elaboration. Usually educators used AM in practical classes contexts. ${ }^{4}$ In this reality, we observe the use of problematizing AM, and learning to learn shows itself as a way to construct knowledge. Proposed interaction on activation results on meaningful learning. ${ }^{16}$

We identified initiatives on AM application, isolated in disciplines, according to approximation by the professor with the method. ${ }^{3}$ In this direction, we highlight the importance so that $A M$ are defined in the course's pedagogical project, from idenfication of teaching sceneries and disciplines' integration, considering a step in the formation..$^{4-16}$ Adopting this method requires curricular restructuring that considers time for activities, work load and articulation with disciplines. ${ }^{17}$

The vision of applicability of problematizing AM in teaching small groups was conceptualized by this study's participants, reinforcing work proposal of AM in the perspective of variety of methods and it's application to small groups. ${ }^{4}$

The study's professors reported students feel overwhelmed by the excess of activities, arguing lack of time to develop PS theoretical deepening. This issue can relate itself to the change 
of teaching strategy and adaptation to the methodology. There are institutions that include AM progressively in the disciplines, maintaining a dominant traditional curriculum. With this, there is a requirement of organizing teaching activities, space and time for professors and students. ${ }^{18}$ Usually, thin time is a limiting factor pf innovative teaching processes. ${ }^{19}$

Issues such as agreed coexisting norms - time, punctuality, attendance and personal presentation - were seen by the group as necessary to professional training. These are present in the teaching approach based on competences, being essential to learn to coexist with independence, prudence and personal commitment. ${ }^{20}$

Participants discussed intensively and themes were defined "evaluation, portfolio and conceptual map" to theorize. On evaluation, they found that discussion was intense and, in some moments, there was dispersion, they suggested agreed pacts to be fulfilled.

\section{Teorization - third, fourth and fifth workshops}

On the third workshop, the group read PS, coordinator questioned participants, while the rapporteur, on the board, wrote concepts and doubts that emerged in discussion, finalizing with the problem question: "How to use evaluation in the teachinglearning process in active methodologies?".

Initial evaluation description was that this must be consensual, normative, additive, a teaching learning instrument capable to promote self-knwoledge. Learning quantitative valorization, mediated through grades, was seen as a challenge. Present additive evaluation process is related to the institutional policy in which grades determinates the student's learning, which will result in approval. ${ }^{15}$ This evaluation is based on mechanical learning, on it the professor verifies knowledge retained by the student repassed by him in the final cycle. This notion is present in the pedagogy of transmission, which does not allow the educator to overcome his deficiencies. ${ }^{8}$

On the sequence, reading of scientific articles previously researched subsided the discussion and new information added them and reinforced evaluation vision with formative, integrative, inclusive and continuous character. In this process, it's necessary to create aims and evaluation criteria based on abilities and competences, in pedagogical strategies adopted in disciplines. On formative evaluation, comparison happens related to the own student's development. ${ }^{21}$

We identified also professors and students share learning development, from potentialities and fragilities, constructing learning possibilities, at times, still not experienced, that can assist on reaching the goals of the discipline. With this, we suggest that evaluation to be based on cognitive skills (theoretical knowlede), practical skills(technical knowledge) and attitudinal skills. ${ }^{15}$ In that sense, the study shows that students that experienced AM in disciplines, evaluated that they obtained essential knowledge, skills and attitudes to professional training. ${ }^{22}$
Formative evaluation result, enabled by the portfolio, reveals that student's and professor's development in the teachinglearning process, both looking for new knowledge, dialoguing and exchanging experiences. On this, we stabilish a closre and more intense relationship and the professor must find ways to incentive the student to commit himself with the problematization method. ${ }^{18}$

By the end of it, participants evaluated the workshop and reported that the experience of construtivist spiral (CS) was considered a moment in which they learned doing so, which was expressed on statements:

"It is like that, this methodology in which we execute the methodology [Construtivist spiral] here in the group is very good! To experience this [...] I'm very satisfied and I'm learning a lot with this part. I already started to talk, we will have a meeting with professors [...] and I put it afterwards on the schedule so we get a professor $x$ with me, so we can start to execute active methodologies, so we see how public adherence it's going to be" (P4).

"I loved the meeting, it amplified my comprehension in the evaluation process" (P6)

On the fourth workshop, there was the problematization of the portfolio theme, from PS with the choice of a new coordinator and rapporteur. The coordinator asked all to do an individual reading on PS. Subsequently, the participants started the questions and the rapporteur recorded them on the board.

On the initial synthesis, the group will feel insecure relating guidance to students about the construction of portfolio and it finalized with the elaboration of two questions: how to conduct the construction of the portfolio? And how to evaluate the portfolio?

Based on the reading of the articles, participants of the study recognized that composition of a portfolio must begin with the presentation of the student's life journey, which enables the professor to know better, aiming to work with humanist skills and competences. In this aspect, on constructing a reflexive portfolio, the student develop an autonomous, participative and commited attitude that is implied in his teaching-learning process. ${ }^{20}$

Professors had knowledge that the portfolio enables to integrate the discription of the student's personal journey, with reflections related to experiences from their practices funded on theory. The search of a theory may occur in several sources, such as reports, photographs, observations, research instruments, support texts, self-reflection, songs, poems. It's a document of it's own with reflections that meant something to the student and, therefore, it's a representation of the experience funded on science. It reveals student's learning growth and, consequently, his transformation. It constitutes a formative strategy that comes from exercising competences of learning to learn, learning to be and learning to coexist. ${ }^{20}$ 
As for moments of advise between the professor and student, workshop faculty participants verified that these meetings are essential to constructing a portfolio with dates previously set up, during the semester, until the final deliver. In this aspect, interaction between the professor and the student is fundamental for learning and evaluation. Portfolio, as a learning method, enables the content comprehension. The mistake, on the portfolio construction is an opportunity to reelaborate knowledge and evaluation is not punishing. Evaluation environment is welcoming and dialogical and affective relation promote transformation on experiences of students in meaningful learning. ${ }^{19}$

Portfolio must be a potent learning instrument but, to adopt it, it is necessary to insert it as a strategy on curricular organization in which the number of students advised by professors doesn't exceed and harm it's construction, once it requires follow up of individual meetings. ${ }^{23}$ On these, the advisor offers the student a learning feedback, talks about weak links, giving opportunities to reelaboration of activities, which can be registered and also potentialities present in learning. Portfolio is an instrument of learning and formative evaluation based on competences. ${ }^{21}$

By the end of it, workshop participants of the faculty reported they were able to create a portfolio and evaluate it, however they felt insecure to develop teaching practice and pointed some challenges such as: students' involvement in the process, have little time, discipline organization with portfolio inclusion, student's work load on the semester and content "detachment".

On the fifth workshop, participants read individual and the coordinator problematized the theme, questioning participants on doubts, while the rapporteur registered key words that emerged in the discussion, while questions were elaborated: "How to construct a conceptual map (CM)?" and "What is the aim of a conceptual map?" Initial description was a map in a visual scheme that represents concepts and their relationships with the theme chosen for the study.

After reading, participants created their concepts about the map, amplifying knowledge and reconstructed the concept: "CM is a tool to represent knowledge about a theme, with concepts through diagram/scheme." Subsequently, they made the map.

On graphical representation (Figure 2), we can observe that there are processes of progressive differentiation and integrative reconciling proposed by Ausubel theory. ${ }^{7}$

CM must be constructed from a focus question. It's theme enables different approaches, and each student or group of students can generate a map to answer that question. It's creation starts from a general concept about the theme to specific concepts, which are disposed hierarchically, enabling comprehension and learning. This way of hierarchy organization that comes from a general theme and, as learning goes it deepens, forms a graphical representation of a network produzed by meaningful learning. ${ }^{24}$
To comprehend better the $\mathrm{CM}$ construction, we resort to Ausubel's Meaningful Learning Theory and Novack's Educational Theory; in this case, information retained by the student is incorporated to their pre-existing knowledge and memory remains intact throughout time. ${ }^{7}$

To elaborate a good CM, it's required training by professors and students, as well as rigorous criteria of proposal's semantic clarity, focus question, hierarchical organization of concepts and continuous revisions. ${ }^{24}$

Meaninful learning theory is base to elaborate manual conceptual maps, because students, on constructing them, trigger their cognitive structure, seeking previous knowledge about the theme and relate with the new through researches, they make conections between general and specific concepts and written graphical representation. ${ }^{25}$

This methodology requires dedication from students being possible to have challenges to overcome, but, on developing this activity, cognitive development happens. CM as a representation model of knowledge can add to other teaching techniques. Learning follow-up with objective and frequent feedbacks can result in a deep learning. ${ }^{26}$

By the end of it, evaluation, participants result in work objectivity of the day, of the importance of previous learning and the possibility to apply a conceptual map on teaching practice, which is confirmed on statements:

We were more objectives, today (P1).

Previous reading on the theme was extremely important, [...] we were objective, I could see the group construction, see the project advisors interviring together (P2).

Previous readings are important, I think that conceptual map gave better perspectives to work than the portfolio. $I$ intend to apply in the discipline next year (P3).

I participated only in this meeting and even though it's a methodology I already applied [...] previous readings were more updated. I liked the discussion (P4).

\section{Hypotheses, solutions and application to reality - sixth workshop}

On the sixth workshop, the participants discussed the hypotheses, solutions and selected the possible methods to be applied in the work contexts, PS based on CS, portfolios and $\mathrm{CM}$ on specific disciplines, such as research methodology, urgency and emergency, sport nutrition and some subjects from them. The intention is in accordance with a pedagogical practice problematizing, progressive and with significant changes. ${ }^{18}$

In this proposal, possible challenges are reported as: lack of partners and supporters of the method, dissonance among those who have partners in the disciplines. There are groups of 
Figure 2. Conceptual map constructed by participants during that workshop.

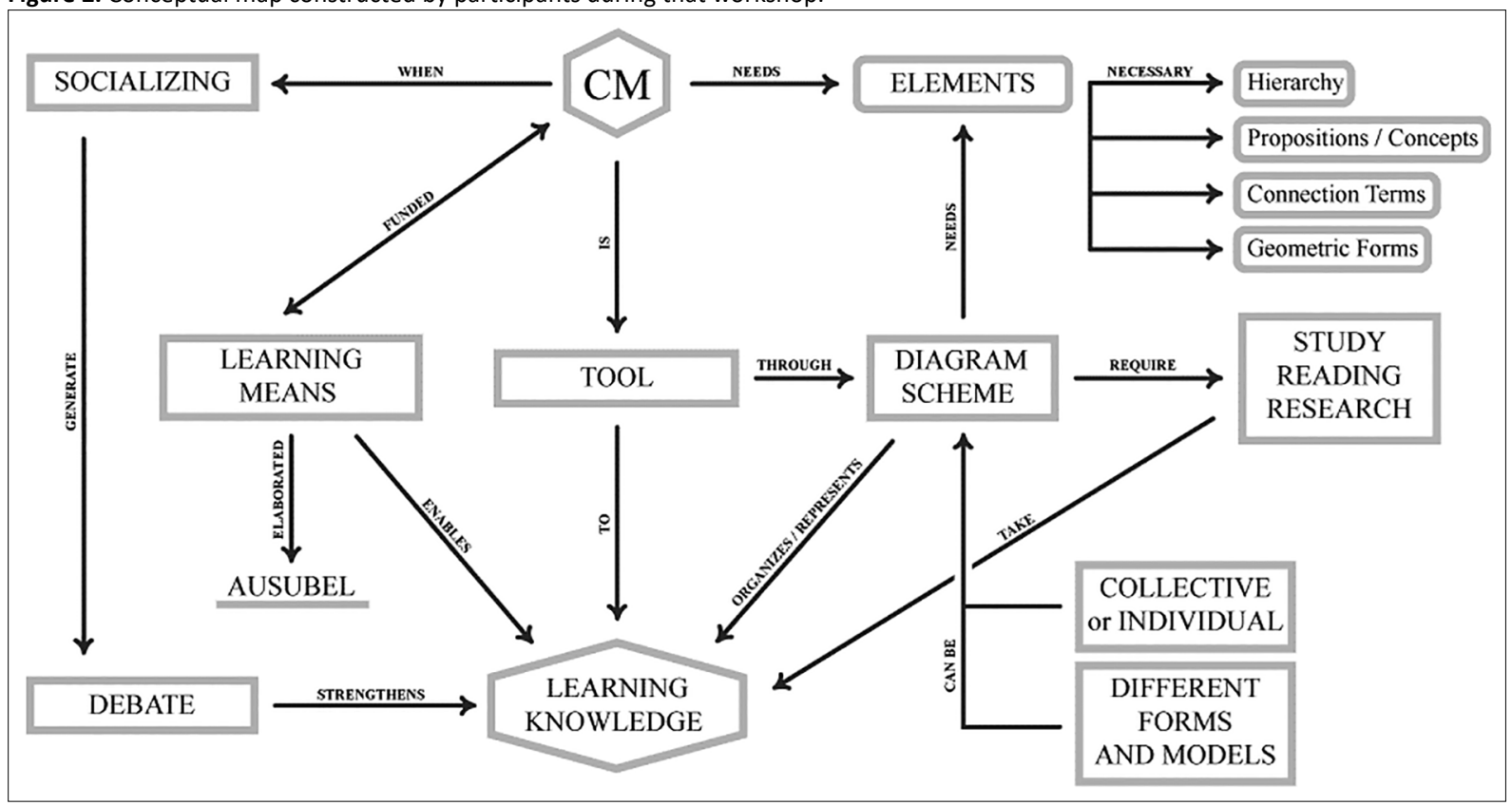

professors that presented resistance to AM and didn't value the method. ${ }^{15-18}$ Many professors find it difficult to update and modify their practices, which prevents problematizing training, which encourages the transformation of social reality. ${ }^{17}$

Application on practice could be experienced by professors, because, at the same time they discussed AM, they used PS methods based on CS and portfolios in their disciplines and extension courses. From those experiences, they found challenges related to the involvement of the students with the method, related to research and reading of the material subside discussions, which they believe to be referred to the innovation of the proposal, because they are not used to receive ready information. Students, on experience AM on teaching of a discipline, they had difficult to accept the principle, due to the fact the method requires reading, reflection, seek to knowledge, which alterates the condition of passive subject of learning to active; but in the end, they recognized the importance of activities to make the process real. ${ }^{22}$

The teaching-learning process must be based on the exchange of knowledge between teachers and students, built in a shared way; for this, it is necessary to know the previous knowledge of the student so that, when stimulated, incorporate new knowledge and re-know the knowledge. ${ }^{15}$

These reflections reinforce the need to strengthen the teaching-learning method, which modifies the traditional mechanisms of knowledge retention, through the segmented transfer of knowledge in a vertical, unified and authoritarian way. ${ }^{18}$

Am aims to make the student proactive and creative and, for that, it is necessary to involve them in more complex activities so they learn to make decisions and evaluate them, based on knowledge, demonstrating creativity from the exposition of new experiences. ${ }^{18}$

At the end of the workshop, during the evaluation, the participants presented some positive and negative points in the following reports:

(...) I think that it was a great learning for all of us, I think everybody took advantage of it. It's a shame not everybody could come, right? (P7).

Well, I want to thank the welcoming, the exchange, the learning, for welcoming me so well, for letting me participate, it was very productive (...) I come with pleasure. Because to me (...) to add knowledge and exchange it, I think that is what strengthens me professionally (...) (P6).

(...) we have to see more learning always and trying to change things that are not going well, there's always a way to improve (...) I think when we like to work with education, we realize that there are things that are wrong, and that is not working anymore, so this makes us uncomfortable (...) what can I do to change this situation? (P4).

The moment of the evaluation allowed the participants to reflect on their teaching practices, which can be improved, and that, because they are professors, need to be in constant pedagogical improvement. They pointed out that the intense activities at the end of the semester prevented other colleagues from participating in the last workshops. Their speeches showed commitment to change, with "doing differently" than they are accustomed to. 


\section{CONCLUSION}

This experience enabled professors to know, discuss and reflect on AM as innovative strategies, as well as propose opportunities and ways to apply activation of learning. It promoted comprehension through experiences on the workshops, highlighting the theorization step with the CS and the classroom approach with PS.

The choice of themes for theorization "evaluation, portifolio and CM" showed participants wished, in fact to study and learn new methods to apply on their teaching practices.

Comprehension of application of AM contributed to transform teaching practices, in a way that these construct possibilities on acting on this high education institution. This way, they identified that disciplines or subjects will act on active methodologies of learning.

With this, we suggest that there is a continuing discussion with the theme of $\mathrm{AM}$ with innovative practice on this context, in order to strenghthen the problematizing and meaningful education conception to a bigger domain of methods, in a way that it can advance on adopting these and other strategies in the academic environment, on disciplines and on pedagogical projects of courses of high education courses in health, according to recommendations of NCGs.

The formation of critical, reflective and transformative health professionals of their realities is closely linked to the pedagogical conceptions that stimulate learning to learn, which can be adopted in the professional practices of health education to the users, families and communities that they will act. Therefore, the discussion and the experience of these methodologies can become an important strategy for the instrumentalization and the performance by these professors.

\section{REFERENCES}

1. Fujita JALM, Carmona EV, Shimo AKK, Mecena EH. Uso da metodologia da problematização com o Arco de Maguerez no ensino sobre brinquedo terapêutico. Rev Port Educação [Internet]. 2016 Jun; [cited 2017 Dec 10]; 29(1):229-58. Available from: http://www.scielo.mec.pt/ scielo.php?script=sci_arttext\&pid=S0871-91872016000100011\&lng =pt\&nrm=iso. http://dx.doi.org/10.21814/rpe.5966

2. Berbel NAN. As metodologias ativas e a promoção da autonomia de estudantes. Semina Ciênc Soc Hum [Internet]. 2011 Jan/Jun; [cited 2017 Dec 10]; 32(1):25-40. Available from: http://www.uel.br/revistas/ uel/index.php/seminasoc/article/view/10326

3. Sobral FR, Campus CJG. Utilização de metodologia ativa no ensino e assistência de enfermagem na produção nacional: revisão integrativa. Rev Esc Enferm USP [Internet]. 2012 Feb; [cited 2017 Dec 10]; 46(1):208-18. Available from: http://www.scielo.br/scielo. php?script=sci_arttext\&pid=S0080-62342012000100028\&lng=en\&n $\mathrm{rm}=\mathrm{iso}$

4. Farias PAM, Martin ALAR, Cristo CS. Aprendizagem Ativa na Educação em Saúde: Percurso Histórico e Aplicações. Rev Bras Educ Méd [Internet]. 2015 Jan/Mar; [cited 2017 Dec 10]; 39(1):143-50. Available from: http://www.scielo.br/scielo.php?script=sci_arttext\&pid=S0100$55022015000100143 \&$ lng $=$ en\&nrm=iso
5. Lima VV. Espiral construtivista: uma metodologia ativa de ensinoaprendizagem. Interface (Botucatu) [Internet]. 2017 Apr/Jun; [cited 2017 Dec 10]; 21(61):421-34. Available from: http:///www.scielo.br/ scielo.php?script=sci_arttext\&pid=S1414-32832017000200421\&Ing =en\&nrm=iso

6. Sousa ATO, Formiga NS, Oliveira SHS, Costa MML, Soares MJGO. Using the theory of meaningful learning in nursing education. Rev Bras Enferm [Internet]. 2015 Jul/Aug; [cited 2017 Dec 10]; 68(4):71322. Available from: http://www.scielo.br/scielo.php?script=sci_ arttext\&pid=S0034-71672015000400713\&Ing=en\&nrm=iso

7. Ausubel DP. The acquisition and retention of knowledge: a cognitive view. Boston: Kluwer Academic Publishers; 2000.

8. Freire P. Pedagogia do oprimido. 50ª ed. São Paulo: Paz e Terra; 2011.

9. Ministério da Educação (BR). Resolução CNE/CES № 3, de 7 de novembro de 2001. Institui Diretrizes Curriculares Nacionais do Curso de Graduação em Enfermagem. Brasília (DF): Diário Oficial da União; 2001.

10. Fernandes JD, Rebouças LC. Uma década de Diretrizes Curriculares Nacionais para a graduação em enfermagem: avanços e desafios. Rev Bras Enferm [Internet]. 2013 Sep; [cited 2018 Mar 18]; 66(no.esp):95101. Available from: http://www.scielo.br/scielo.php?script=sci_arttex t\&pid=S0034-71672013000700013

11. Conterno SFR, Lopes RE. Pressupostos pedagógicos das atuais propostas de formação superior em saúde no Brasil: origens históricas e fundamentos teóricos. Avaliação (Campinas) [Internet].2016 Aug/Nov; [cited 2017 Dec 10]; 21(3):993-1016. Available from: http://www.scielo. br/scielo.php?script=sci_arttext\&pid=S1414-40772016000300993\&In $\mathrm{g}=\mathrm{en} \& \mathrm{nrm}=$ iso

12. Prado ML, Velho MB, Espíndola DS, Sobrinho SH, Backes VMS Arco de Charles Maguerez: refletindo estratégias de metodologia ativa na formação de profissionais de saúde. Esc Anna Nery [Internet]. 2012 Mar; [cited 2017 Dec 10]; 16(1):172-7. Available from: http://www.scielo.br/scielo.php?script=sci_arttext\&pid=S1414$81452012000100023 \&$ Ing=en. http://dx.doi.org/10.1590/S141481452012000100023.1

13. Berbel NAN. A Metodologia da Problematização com o Arco de Maguerez: uma reflexão teórico-epistemológica. Londrina: EDUEL 2012.

14. Bordenave JD, Pereira AM. Estratégias de ensino-aprendizagem. $22^{a}$ ed. Petrópolis: Vozes; 2001

15. Freitas DA, Santos EMS, Lima LVS, Miranda LN, Vasconcelos EL, Nagliate PC. Saberes docentes sobre processo ensino-aprendizagem e sua importância para a formação. Interface (Botucatu) [Internet]. 2016; [cited 2017 Dec 10]; 20(57):437-48. Available from: http://www.scielo. br/pdf/icse/v20n57/1807-5762-icse-1807-576220141177.pdf

16. Vieira MNCM, Panúncio-Pinto MP. A Metodologia da Problematização (MP) como estratégia de integração ensino-serviço em cursos de graduação na área da saúde. Medicina (Ribeirão Preto) [Internet]. 2015; [cited 2017 Dec 10]; 48(3):241-8. Available from: http://www.revistas. usp.br/rmrp/article/view/104310

17. Mesquita SKC, Menezes RMV, Ramos DKR. Metodologias ativas de ensino/aprendizagem: dificuldades de docentes de um curso de Enfermagem. Trab Educ Saúde [Internet]. 2016; [cited 2017 Dec 10]; 14(2):473-86. Available from: http://www.scielo.br/scielo. php?pid=S1981-77462016000200473\&script=sci_abstract\&tlng=pt

18. Morin J. Mudando a educação com metodologias ativas. Formato E-Book. In: Souza CA, Morales OET, organizadores. Convergências Midiáticas, Educação e Cidadania: aproximações jovens (Mídias Contemporâneas, 2). Ponta Grossa: UEPG/PROEX; 2015. p. 15-33.

19. Costa GD, Cotta RMM. Aprender fazendo: representações sociais de estudantes da saúde sobre o portfólio reflexivo como método de ensino, aprendizagem e avaliação. Interface (Botucatu) [Internet]. 2014; [cited 2017 Dec 10]; 18(51):771-84. Available from: http://www. scielo.br/scielo.php?pid=S1414-32832014000400771\&script=sci_ abstract\&tlng=pt 
20. Cotta MMR, Costa GD, Mendonça ET. Portfólio reflexivo: uma proposta de ensino e aprendizagem orientada por competências. Ciênc Saúde Coletiva [Internet]. 2013; [cited 2017 Dec 10]; 18(6):184756. Available from: http://www.scielo.br/scielo. php?pid=S1413$81232013000600035 \&$ script=sci_abstract\&tlng=es

21. Cesário JB, Ribeiro MRR, Dias RBF, Rothebarth AP, Lima LPS. Portfólio Reflexivo como estratégia de avaliação formativa. Rev Baiana Enferm [Internet]. 2016 Jan/Mar; [cited 2017 Dec 10]; 3(1):356-64. Available from: https://portalseer.ufba.br/index.php/enfermagem/article/ viewFile/14500/pdf_34

22. Silva LS, Cotta MMR, Costa GD, Campos AAO, Cotta RM, Silva LS, Cotta FM. Formação de profissionais críticos-reflexivos: o potencial das metodologias ativas de ensino-aprendizagem e avaliação na aprendizagem significativa. Rev CIDUI [Internet]. 2014; [cited 2017 Dec 10]; 2:1-16. Available from: http://www.cidui.org/revistacidui/index.php/ cidui/article/view/541/522

23. Pereira EG, So KNS, Ciosak SI, Otrenti E, Nichiata LYI. Portfólio no ensino em Saúde: contribuição a reflexão a partir de seu uso na disciplina de Enfermagem em Doenças Transmissíveis. ABCS Health Sci [Internet]. 2015; [cited 2017 Dec 10]; 40(3):329-32. Available from: https://www.portalnepas.org.br/abcshs/article/view/816
24. Aguiar JG, Correia PRM. Como fazer bons mapas conceituais? Estabelecendo parâmetros de referências e propondo atividades de treinamento. Rev Bras Pesq Educ Ciênc [Internet]. 2013; [cited 2017 Dec 10]; 13(2):141-57. Available from: https://seer.ufmg.br/index.php/ rbpec/article/view/2469

25. Carvalho DPSRP, Rego ALC, Ferreira KS, Silva SB, Vitor AF, Ferreira Júnior MA. Teoria da aprendizagem significativa como proposta para inovação no ensino de enfermagem: experiência dos estudantes. Rev Enferm UFSM [Internet]. 2015 Jan/Mar; [cited 2017 Dec 11]; 5(1):186-92. Available from: https://periodicos.ufsm.br/reufsm/article/view/13210

26. Correia PRM, Aguiar JG, Viana AD, Cabral GC. Por Que Vale a Pena Usar Mapas Conceituais no Ensino Superior? Rev Grad USP [Internet]. 2016 Jul; [cited 2017 Dec 10]; 1(1):41-52. Available from: https://edisciplinas. usp.br/pluginfile.php/4243194/mod_resource/content $/ 1 / 2016 \% 20$ USP\%20mapaconceitual.pdf 